\title{
CXCR6 wt Allele
}

National Cancer Institute

\section{Source}

National Cancer Institute. CXCR6 wt Allele. NCI Thesaurus. Code C51339.

Human CXCR6 wild-type allele is located within 3p21 and is approximately $5 \mathrm{~kb}$ in length.

This allele, which encodes C-X-C chemokine receptor type 6 protein, is involved in

interactions between dendritic cells and T cells and in regulating T-cell migration in splenic red pulp. 